\title{
Biological Agent Nucleotide Sequence Indicator
}

National Cancer Institute

\section{Source}

National Cancer Institute. Biological Agent Nucleotide Sequence Indicator. NCI

Thesaurus. Code C158312.

An indication as to whether the genetic sequence of the challenge agent has been identified. 